\title{
Assessment of prolactin associated platelet activation in ischemic stroke
}

\author{
İsemik inmede prolaktin ilişsili platelet aktivasyonunun değerlendirilmesi
}

\author{
Ayşegül Akagündüz Ege, Şule Bilen, Fikri Ak \\ Neurology Clinic of Ankara Numune Education and Research Hospital, Ankara, Turkey
}

\section{ABSTRACT}

Objectives: We aimed to investigate whether there were any relations between prolactin levels, prolactin associated platelet activation and ischemic stroke, and whether they had role in etiology of ischemic stroke.

Materials and methods: Totally 57 patients with the diagnosis of acute ischemic stroke and 43 age and sex matched controls with no history of ischemic vascular diseases were included in the study. Prolactin levels, mean platelet volume (MPV) a marker of platelet activation, and platelet count, of the patients, after 12 hours of fasting, compared with the measurements of control group.

Results: Patients had significantly higher prolactin levels. A correlation between prolactin levels and early measurements of MPV was not detected. While there was no difference in terms of MPV, the platelet count was significantly higher in the patient group.

Conclusions: In the present study, the existence of an effect of prolactin on the mean platelet volume, or a relationship between early ischemic stroke and MPV could not be shown. However, in ischemic stroke patients, in early phase, presence of higher levels of prolactin and platelet count may be meaningful in etiology of ischemic events. Besides, presence of higher prolactin levels in early phase of ischemic stroke may lead to consider the potential role of prolactin elevation in ischemic stroke pathogenesis. J Clin Exp Invest 2012; 3(1): 1-6

Key words: Ischemic stroke, prolactin, mean platelet volume, platelet count

\section{INTRODUCTION}

Cerebrovascular disease is one of the most frequently occurring and significant neurological disorders among the adult population.

Today, it is a widely accepted view that the risk of ischemic stroke is increased by a number of factors that can be classified as modifiable and nonmodifiable. Non-modifiable risk factors for stroke include advanced age, male gender, ethnic group and

\section{ÖZET}

Amaç: İskemik inme ile prolaktin seviyeleri, prolaktin ilişkili platelet aktivasyonu arasında ilişki olup olmadığı ve iskemik inme etyolojisinde rolleri olup olmadığının araştırılmasını amaçladık.

Gereç ve yöntem: Çalışmaya akut iskemik inme tanısı almış olan 57 hasta ile iskemik vasküler hastalık hikayesi olmayan, yaş ve cinsiyet uyumlu 43 kontrol olgusu dahil edildi. Hastaların 12 saat açlığı takiben değerlendirilen prolaktin seviyeleri, platelet sayısı ve platelet aktivasyonunun bir göstergesi olan ortalama platelet hacmi (OPH) kontrol grubunun ölçümleri ile karşılaştırıldı.

Bulgular: Hastaların prolaktin seviyeleri anlamlı şekilde yüksekti. Prolaktin seviyeleri ile erken OPH ölçümleri arasında bir ilişki bulunmadı. OPH açısından bir fark yok iken platelet sayısı hasta grubunda anlamlı şekilde yüksekti.

Sonuç: Bu çalışmada prolaktinin ortalama platelet hacmi üzerinde bir etkisinin varlığı veya erken iskemik inme ve $\mathrm{OPH}$ arasında bir ilişki gösterilememiştir. Ancak iskemik inmeli hastalarda, erken dönemde yüksek prolaktin seviyesi ve yüksek platelet sayısı varlığı iskemik olayların etyolojisinde anlamlı olabilir. Bunun yanı sıra iskemik inmenin erken döneminde yüksek prolaktin seviyesi bulunması iskemik inmenin patogenezinde prolaktin artışının rolü olabileceğini düşündürebilir.

Anahtar kelimeler: İskemik inme, prolaktin, ortalama platelet hacmi, platelet sayısı

a family history of stroke. Modifiable risk factors are divided into two separate groups, which in turn are categorized as lifestyle dependent and non-lifestyle dependent risks. Lifestyle-dependent risk factors include smoking and illicit drug use. Risk factors independent of lifestyle include low socioeconomic status, arterial hypertension, dyslipidemia, heart disease and asymptomatic carotid artery disease. ${ }^{1}$ In addition to these factors, several potential risk factors have also been identified in recent years. 
The identification of new risk factors contributes to a better understanding of the pathophysiology of the disease and possible treatment strategies. Platelet activation and aggregation have been shown to play an important role in the pathophysiology of atherosclerosis and thrombosis in acute and chronic arterial diseases. ${ }^{2,3}$ Prolactin is known to contribute to this process by increasing platelet activation. Mean platelet volume is an indicator of platelet activation. Larger-sized platelets are more reactive and many phases of this activation are mediated via ADP and P-selectin expression on which prolactin has a direct effect. ${ }^{4}$ These pathophysiological processes are thought to be also relevant in ischemic stroke. ${ }^{5-10}$ In addition, prolactin has been described as causing increased in vivo and in vitro platelet aggregation. ${ }^{11}$ and increased platelet aggregation as arising with the effect of prolactin; ${ }^{12}$ and these processes are thought to contribute to the pathophysiology of stroke.

In this study, we aimed to investigate the relationship of prolactin levels and platelet activation associated with prolactin to the risk of ischemic stroke, and whether they have a role in its etiology.

\section{MATERIALS AND METHODS}

Patients monitored following diagnosis of acute ischemic cerebrovascular event at the Neurology Clinics of Ankara Numune Education and Research Hospital between June 2008 and September 2009 were randomized and enrolled in the study. The control group included age and gender matched individuals who met the defined inclusion criteria. Patients' histories, neurological examinations, and brain images (computed tomography and/or magnetic resonance imaging) were used for the diagnosis of ischemic cerebrovascular events. Presence of peripheral arterial disease, coronary artery disease, chronic diseases (hypertension, diabetes mellitus, chronic renal failure, endocrine / metabolic disorders, malignancies), previous surgical procedures and head trauma, alcohol consumption and substance abuse were asked.

Alcohol consumption, substance users, those who had undergone intracranial surgery, epileptics, those with intracranial mass, metabolic and endocrine diseases, chronic renal failure, hepatic failure, malignancies, autoimmune and collagen tissue diseases and those using drugs that alter prolactin metabolism (anti-psychotics, various hormone treatments) were excluded from the study. Also excluded were individuals with abnormal platelet counts and/or platelet dysfunction, proliferative bone mar- row disease and hematological conditions leading to bone marrow suppression, those using various drugs that have indirect effects on bone marrow, and those with chronic diseases.

Subjects selected for the control group were people with no history of ischemic cerebrovascular accident, myocardial infarction and peripheral artery disease. Individuals with prolactin metabolism disorders and bone marrow dysfunction were also excluded from the control group.

There were 57 subjects ( 29 females, 28 males) in the patient group and 43 subjects ( 23 female and 20 male) in the control group.

Blood samples were taken from all participating subjects (from the patient group within the first day of hospital admission) after 12 hours of fasting for analysis of biochemical parameters (blood glucose, liver function tests, BUN, creatinine, electrolytes, albumin, globulin), lipid panel (LDL cholesterol, HDL cholesterol , VLDL cholesterol, total cholesterol and triglyceride levels), thyroid function tests (free T3, free T4, TSH), complete blood count, erythrocyte sedimentation rate (ESR) and C-reactive protein (CRP). Neurological examinations of the patient group were evaluated on day 1 and day 10, using the modified Rankin Scale. ${ }^{13}$ Electrocardiograms (ECG) and carotid and vertebral artery doppler ultrasound (US) scans were performed on all individuals in the patient group. Prolactin levels after 12 hours of fasting were determined in both groups (in patients in the first day of admission).

Prolactin levels were determined using the Chemiluminescent Microparticle Immunoassay (CMIA) method of the Beckman Coulter DXI Analyzer system. Platelet count and mean platelet volume were determined on a Coulter Gen S complete blood count device.

\section{Statistical analysis}

SPSS for Windows software version 15.0 was used in the statistical analysis. Quantitative parameters were examined in terms of mean, standard deviation and median. Qualitative parameters were demonstrated in terms of numbers and percentages. The differences in quantitative parameters between the two groups were examined using the t-test or Mann Whitney test, and the Kruskal-Wallis test was used to identify any differences between the three groups analyzed. The Chi-square test was used to identify any significant differences in terms of gender distribution between groups. The relationship between quantitative parameters was shown with the Spearman's correlation coefficient. The significance level was determined as $p<0.05$. 


\section{RESULTS}

A total of 100 individuals were included in the study. The patient and control groups consisted of 57 and 43 individuals respectively. There was no significant statistical difference between the mean ages of the patient $(74.8 \pm 8.0)$ and control $(71.6 \pm 6.9)$ groups $(p=0.214)$. There were 29 females $(50.9 \%)$ and 28 males $(49.1 \%)$ in the patient group, and 23 females $(53.5 \%)$ and 20 males $(46.5 \%)$ in the control group. The gender distribution of subjects in the patient and control groups did not differ significantly $(p=$ 0.955).

The mean prolactin level was $10.4 \mathrm{mg} / \mathrm{dl}(15.3$ $\pm 15.9)$ and $6.6 \mathrm{mg} / \mathrm{dl}(7.7 \pm 3.8)$ respectively in the patient and control groups. In the patient group, the mean prolactin level was significantly higher compared to the control group $(p=0.001)$. However, a comparison of CRP levels between the patient and control groups revealed the average value in the patient group to be significantly higher $(10.5 \pm 26.2$ $\mathrm{mg} / \mathrm{dl}$, mean $=3.0 \mathrm{mg} / \mathrm{dl}, 0.7 \pm 0.5 \mathrm{mg} / \mathrm{dl}$, mean = $0.5 \mathrm{mg} / \mathrm{dl}$ respectively) $(p<0.001)$ (Figure 1$)$. Within the patient group CRP levels showed a positive correlation with prolactin levels (SCC: $0.308, p=$ 0.002 ). Platelet count measured in the patient group $(279,596.5 \pm 101,065.9 / \mathrm{ml})$ was higher than the control group's platelet count (243651.2 \pm 65638.6 $/ \mathrm{ml})$, and it was statistically significant $(p=0.034)$. Table 1 indicates significant differences between the two groups.

Table 1. Prolactin levels, platelet counts and C-reactive protein levels of patients and controls

\begin{tabular}{llll}
\hline & Patients $(\mathrm{n}=57)$ & Controls $(\mathrm{n}=43)$ & $P$ \\
\hline Prolactin levels $(\mathrm{mg} / \mathrm{dl})$ & $15.3 \pm 15.9$ (Median=10.4) & $7.7 \pm 3.8$ (Median=6.6) & 0.001 \\
Platelet count, $(/ \mu \mathrm{l})$ & $279.596 \pm 101.065$ & $243.651 \pm 656.38 \mathrm{l}$ & 0.034 \\
C-reactive protein $(\mathrm{mg} / \mathrm{dl})$ & $10.5 \pm 26.2$ (Median=3.0) & $0.7 \pm 0.5($ Median=0.5) & $<0.001$ \\
\hline
\end{tabular}

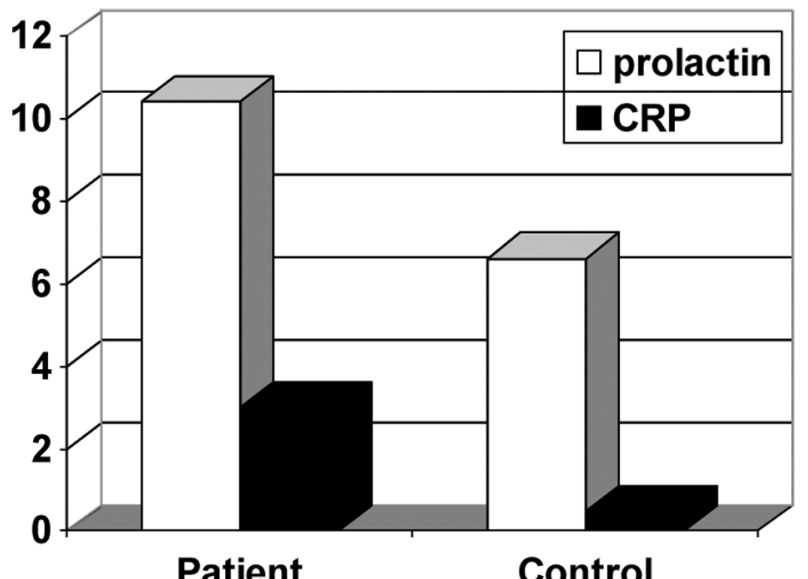

Figure 1. Comparison of prolactin and C-reactive protein (CRP) levels of patient and control group

The patient and control groups did not differ significantly in terms of MPV $(P=0.699)$. MPV values of the patient and control groups were $8.2 \pm 1.0$ $\mathrm{fl}$ and $8.1 \pm 1.0 \mathrm{fl}$ respectively. In the patient group, mean platelet volume (SCC: $-0.118, p=0.224$ ), platelet count (SCC: 0.063, $p=0.531$ ) and ESR (SCC: $0.109, p=0.368$ ) did not show a significant correlation with prolactin levels.

When the relationship between prolactin levels and carotid artery pathology was analyzed in the pa- tient group, we found that there was no significant relationship between prolactin levels and those of isolated intima-media thickness $(n=5,19.5 \pm 24.4$, mean $=8)$, those with non-stenotic plaques $(n=28$, $18.2 \pm 19.2$, mean $=11.7$ ) and those with stenotic plaques $(n=23,11.3 \pm 7.1$, mean $=9.5)$.

In the patient group, there was no significant correlation between prolactin levels and the presence of hypertension $(n=47,16.0 \pm 17.2$, mean $=10.4, p=0.690)$, diabetes mellitus $(n=18,14.1$ \pm 14.7 , mean: 8.9, $p=0.542)$, atrial fibrillation $(n=$ $14,12.8 \pm 9.2$, mean: $11, p=0.831$ ) and coronary artery disease $(n=26,13.8 \pm 12.6$, mean: 10.3, $p$ $=0.816)$.

No significant correlation was observed in the baseline and end-of-study modified Rankin scores of the patient group when compared with prolactin levels $(p=0.371)$, mean platelet volume $(p=0.802)$, platelet count (0382), and CRP levels ( $p=0.903)$.

\section{DISCUSSION}

Ischemic cerebrovascular disease is a health problem of growing significance given the aging population. In addition to well-known risk factors for stroke, many potential risk factors have been defined in recent years, and some of these have begun to be used for screening purposes. Today, clinical and 
laboratory data are available which suggest that elevated prolactin levels may be related to the disease in some measure. In our study, the patient group had significantly higher prolactin levels compared with healthy controls. These findings suggest that prolactin contributes to the pathophysiology of ischemic cerebrovascular event. Prolactin contributes to this process by increasing platelet activation. Wallaschofski et al demonstrated the in vivo and in vitro dose-dependent expression of CD62p with prolactin in patients undergoing cerebrovascular ischemic event, and increased prolactin levels were shown in the blood of patients with ischemic stroke and transient ischemic attack. ${ }^{14}$ The same investigator group also noted the higher rates of venous thromboembolism in patients with prolactinoma. ${ }^{15}$ The authors attributed these results to increased platelet activation by prolactin via ADP. ${ }^{11,12}$ Similarly, Raaz et al claimed that prolactin increases ADP stimulated P-selectin expression in patients with acute coronary syndrome. ${ }^{14}$

Our findings are consistent with the current literature. However, Schwarz et al attribute these findings to hypothalamic-pituitary-adrenocortical axis disturbances. ${ }^{16}$ Serum prolactin levels are also known to increase secondarily to psychogenic and physical stress. ${ }^{17}$ Despite an absent or low-level endogenous stress response in central nervous system lesions, they suggest that increasing levels of prolactin in these patients are due to impairments caused by lesions of the dopaminergic pathways. ${ }^{16}$ However, it is debatable whether this hypothesis is applicable to all ischemic patients since the Schwarz et al study includes only large space-occupying ischemic stroke patients. In our study, ischemic stroke patients were randomized regardless of the infarct size and increased intracranial pressure, providing the opportunity to monitor stroke pathophysiology more directly. We found that there was a significant correlation between CRP levels and prolactin elevation, but that CRP levels were unrelated to the modified Rankin Scale. In this case, one may speculate that the prolactin levels we found may reflect an earlier pro-inflammatory process rather than the severity of the existing disease. However, more studies are needed to clarify whether increased prolactin levels are a primary or secondary phenomenon. Although the endogenous stress response was not triggered sufficiently to raise levels of prolactin in central nervous system lesions, there are prospective clinical trials available in literature to reveal this relationship.

Prolactin is known to contribute to the process by increasing platelet activation. We made use of mean platelet volume measurements to assess this activation. Mean platelet volume is an indicator of platelet activation. Larger-sized platelets are more reactive and many phases of this activation are mediated via ADP and P-selectin expression on which prolactin has a direct effect. In our study, we did not detect a significant difference in MPV between the patient and control groups. When evaluated as a whole in literature, studies investigating the association between the risk and and prognostic impact of MPV measurements in patients with ischemic stroke currently show conflicting data. The first question is whether MPV elevation emerges before or after the disease, and the second is whether persistent MPV elevation has a positive relationship with subsequent vascular events. In a large series of 3134 patients with a history of cerebrovascular disease, Bath and colleagues concluded that there is a positive relationship between high platelet volume and the risk of ischemic stroke. ${ }^{4}$

Greisenegger et al noted that higher MPV values lead to an up to twofold increase in the risk of stroke, particularly in the group with higher MPV values. ${ }^{18} \mathrm{~A}$ similar clinical trial has demonstrated a positive correlation between poor prognosis after three months and elevated MPV. ${ }^{19}$ Contrary to these results, O' Malley et al suggested that there is no relationship between platelet behavior and prognosis after six months..$^{20}$ In the light of current laboratory research data, it is concluded today that MPV is associated with production phases in the bone marrow and that a variety of cytokines play a role in this process, but the same result has not always been supported by clinical studies. An increase in MPV and decrease in platelet counts have been reported after myocardial infarction, ${ }^{21}$ and similar trends in platelet ischemic stroke may also apply. It is suggested that MPV increases reactively as platelet count decreases. One theory that attempts to explain increased MPV is the retention of platelets in the infarct areas and volume changes occurring subsequently. ${ }^{21,22} \mathrm{~A}$ similar study shows that in cerebral ischemic stroke the number of platelets decreased and MPV increased during the 48 hours following cerebral infarction. ${ }^{22}$ This occurrence may be related to the emergence of young platelets with high MPV in peripheral circulation as a response to the decrease in numbers caused by the retention of platelets in the infarct area. Elevated MPV may persist for one month after the acute event. Another study shows decreases in both platelet number and MPV following cerebral thrombosis, and suggests by way of explanation that the selective loss of large and active platelets in the infarct regions during the pathological process played an influential role in 
the results. ${ }^{9}$ Many investigators attribute the reason for these contradictory results to low patient numbers and the designation of different criteria for the results. Our results reflect MPV values measured within the first 12 hours after ischemic stroke. Our results indicate that there was no increase in platelet volume prior to the thrombotic process. Since serial MPV measurements were not taken in our study, we cannot form an opinion as to whether there was a falling or rising trend. However, MPV measurements showed no significant difference when prolactin levels were elevated, and this may be due to the fact that platelets are able to demonstrate different forms of activation. For example, some researchers have identified the presence of an isolated enzymatic activation, and indeed shown that high rates of ATP activity can be found even at stages when aggregation is not at adequate levels. ${ }^{8,9}$ Nevertheless, it is arguable to what extent this contributes to the pathophysiology of thrombosis. Another explanation for our results may be a negative relationship between platelet count and mean platelet volume. In blood samples taken within the first 12 hours, the number of platelets in the patient group was significantly higher compared with controls, which may explain low MPV values (MPV decreases as platelet count increases). Nevertheless, the fact that platelet numbers were significantly higher than in controls suggests a platelet-derived predisposition in stroke patients. An alternative point of view is that tissue ischemia and oxidative stress are known to trigger platelet activation, ${ }^{23}$ and that MPV was initially low in our patients due to the likelihood of platelet activity being a secondary phenomenon for these very reasons. In order to verify this information, there is a need for prospective studies where serial measurements of MPV and platelet counts are taken.

In one study, MPV elevation was found to be associated with poor prognosis independently of concomitant factors. ${ }^{18}$ Although this phenomenon is well-known in coronary artery disease, there are not any adequate studies among patients with ischemic stroke. In our study we were unable to demonstrate a relationship between modified Rankin scores measured on day 1 and day 10 and platelet count and MPV. The view that platelet activity is more marked in more severe strokes was not supported with these results. Nevertheless, we found no correlation between prolactin levels and modified Rankin scores. Although prolactin increases the risk of ischemic stroke through platelet activation, further work is needed to reveal the relationship between this pathophysiological process and prognosis.
In summary, our study supports the hypothesis that ischemic stroke patients have higher levels of prolactin; however, prolactin is not correlated with early MPV measurements as a marker of platelet activation. If new clinical trials are conducted to investigate whether prolactin is a risk factor for ischemic stroke, how prolactin relates to prognosis and to what extent it contributes to platelet activation, this will reduce the existing question marks.

\section{REFERENCES}

1. Biller J, Love BB, Schneck MJ. Ischemic cerebrovascular disease.In Bradley WJ, Daroff RB, Fenichel GM, Jankovic J, eds. Neurology in Clinical Practice 5th edn. Butterworth-Heinemann . Elsevier, 2008:11651220.

2. Ruggeri ZM.; Platelets in atherothrombosis. Nat Med 2002;8(11):1227-34.

3. Gawaz M, Langer $H$, May AE. Platelets in inflammation and atherogenesis. J Clin Invest 2005;115(12):337884.

4. Bath P, Algert C, Chapman N, Neal B. Association of mean platelet volume with risk of stroke among 3134 individuals with history of cerebrovascular disease. PROGRESS Collaborative Group. Stroke 2004;35(3):622-6.

5. Fateh-Moghadam S, Htun P, Tomandl B et al. Hyperresponsiveness of platelets in ischemic stroke. Thromb Haemost 2007;97(6):974-8.

6. Fisher M, Levine PH, Fullerton AL et al. Marker proteins of platelet activation in patients with cerebrovascular disease. Arch Neurol 1982;39(11):692-5.

7. Fisher M, Francis R. Altered coagulation in cerebral ischemia. Platelet, thrombin, and plasmin activity. Arch Neurol 1990;47(10):1075-9.

8. Joseph R, D'Andrea G, Oster SB, Welch KM. Whole blood platelet function in acute ischemic stroke. Importance of dense body secretion and effects of antithrombotic agents. Stroke 1989;20(1):38-44.

9. Tohgi H, Suzuki H, Tamura K, Kimura B. Platelet volume, aggregation, and adenosine triphosphate release in cerebral thrombosis. Stroke 1991;22(1):17-21

10. Serebruany VL, Malinin Al, Oshrine BR et al. Lack of uniform platelet activation in patients after ischemic stroke and choice of antiplatelet therapy. Thromb Res 2004;113(3-4):197-204.

11. Wallaschofski $H$, Donné $M$, Eigenthaler $M$ et al. $P R L$ as a novel potent cofactor for platelet aggregation. J Clin Endocrinol Metab 2001;86(12):5912-9

12. Wallaschofski $H$, Kobsar A, Sokolova O, Eigenthaler M, Lohmann T. Co-activation of platelets by prolactin or leptin-pathophysiological findings and clinical implications. Horm Metab Res 2004;36(1):1-6.

13. Wilson JL, Hareendran A, Hendry A, et al. Reliability of the modified rankin scale across multiple raters: 
benefits of a structured interview. Stroke 2005;36: 777-81.

14. Raaz D, Wallaschofski $H$, Stumpf $C$ et al. Increased prolactin in acute coronary syndromes as putative Co-activator of ADP-stimulated P-selectin expression. Horm Metab Res 2006;38(11):767-72.

15. Wallaschofski $H$, Kobsar A, Koksch M et al. Prolactin receptor signaling during platelet activation. Horm Metab Res 2003;35(4):228-35.

16. Schwarz S, Schwab S, Klinga K, Maser-Gluth C, Bettendorf M. Neuroendocrine changes in patients with acute space occupying ischaemic stroke. J Neurol Neurosurg Psychiatry 2003;74(6):725-7.

17. Van den Berghe G, de Zegher F, Bouillon R. Clinical review 95: Acute and prolonged critical illness as different neuroendocrine paradigms. J Clin Endocrinol Metab 1998;83(6):1827-34.

18. Greisenegger S, Endler G, Hsieh K, Tentschert S, Mannhalter C, Lalouschek W. Is elevated mean plate- let volume associated with a worse outcome in patients with acute ischemic cerebrovascular events? Stroke 2004;35(7):1688-91.

19. Kinlough-Rathbone RL, Mustard JF, Packham MA, Harfenist EJ. Factors influencing the deaggregation of chymotrypsin-treated human platelets aggregated by fibrinogen. Thromb Haemost 1983 28;49(3):196-8.

20. O'Malley T, Langhorne P, Elton RA, Stewart C. Platelet size in stroke patients. Stroke 1995;26(6):995-9.

21. Jackson SR, Carter JM. Platelet volume: laboratory measurement and clinical application. Blood Rev 1993;7(2):104-13.

22. D'Erasmo E, Aliberti G, Celi FS, Romagnoli E, Vecci E, Mazzuoli GF. Platelet count, mean platelet volume and their relation to prognosis in cerebral infarction. $\mathrm{J}$ Intern Med 1990;227(1):11-4.

23. Shah AB, Beamer N. Enhanced in vivo platelet activation in subtypes of ischemic stroke. Coull BM. Stroke 1985;16(4):643-7. 